\title{
Role of the $\alpha$-adrenoceptor in regulating noradrenaline overflow by nerve stimulation
}

\author{
MARÍA A. ENERO, S. Z. LANGER, R. P. ROTHLIN AND F. J. E. STEFANO
}

Instituto de Investigaciones Farmacológicas, Consejo Nacional de Investigaciones Científicas y Técnicas, Paraguay 2155, Buenos Aires, Argentina

\section{Summary}

1. A study of the actions of phenoxybenzamine on transmitter overflow, neuronal and extraneuronal uptake of noradrenaline and in causing $\alpha$-adrenoceptor blockade was carried out using the isolated cat nictitating membrane preparation.

2. Phenoxybenzamine increased transmitter overflow elicited by nerve-stimulation at $10 \mathrm{~Hz}$ in a concentration dependent manner in the range $10^{-8}$ to $10^{-5}$ $\mathrm{g} / \mathrm{ml}$.

3. Neuronal uptake of $\left[{ }^{3} \mathrm{H}\right]$-noradrenaline was not inhibited by concentrations lower than $10^{-6} \mathrm{~g} / \mathrm{ml}$ of phenoxybenzamine. With $10^{-7} \mathrm{~g} / \mathrm{ml}$ of phenoxybenzamine a significant increase in transmitter overflow was obtained, although neuronal uptake of noradrenaline was not affected. Higher concentrations of phenoxybenzamine $\left(10^{-6}\right.$ and $\left.10^{-5} \mathrm{~g} / \mathrm{ml}\right)$ inhibited the neuronal uptake of noradrenaline and further increased transmitter overflow.

4. Extraneuronal uptake of $\left[{ }^{3} \mathrm{H}\right]$-noradrenaline was inhibited only with the highest concentration of phenoxybenzamine tested $\left(10^{-5} \mathrm{~g} / \mathrm{ml}\right)$ and therefore appears to be unrelated to the effects on transmitter overflow.

5. There was a significant correlation between the degree of $\alpha$-adrenoceptor block produced by phenoxybenzamine and the increase in transmitter overflow obtained by nerve stimulation.

6. These results indicate that phenoxybenzamine, in addition to increasing overflow by preventing reuptake of noradrenaline, may increase transmitter release.

7. The possibility that phenoxybenzamine acts on $\alpha$-adrenoceptors in the adrenergic nerve terminal is discussed. These receptors would be involved in a negative feedback mechanism regulating transmitter release.

\section{Introduction}

Phenoxybenzamine increases the overflow of noradrenaline elicited by nerve stimulation (Brown \& Gillespie, 1957 ; Haefely, Hürlimann \& Thoenen, 1965 ; Langer, 1970). Initially the effect of phenoxybenzamine was attributed to its ability to block the $\alpha$-adrenoceptors (Brown \& Gillespie, 1957) but it was later correlated with the inhibition of neuronal uptake of noradrenaline (Thoenen, Hürlimann \& Haefely, 1964). It was shown subsequently that phenoxybenzamine inhibits extraneuronal uptake of noradrenaline (Iversen, 1967) and that it also prevents the access of noradrenaline released by nerve stimulation to the extraneuronal metabolizing 
enzymes (Langer, 1970). Furthermore, it has been suggested that phenoxybenzamine may increase the release of noradrenaline per stimulus (Langer, 1970).

The aim of the present study was to correlate, for several concentrations of phenoxybenzamine, the effects on the following parameters using the isolated nictitating membrane of the cat: (1) overflow of transmitter elicited by nerve stimulation ; (2) blockade of $\alpha$-adrenoceptors ; (3) neuronal uptake of noradrenaline and (4) extraneuronal uptake of noradrenaline.

Some of the findings described in the paper have been presented at a meeting of the Argentinian Society for Clinical Research (Langer, Enero, Stefano \& Rothlin, 1970) and at the 25th International Congress of Physiological Sciences (Langer, Adler, Enero \& Stefano, 1971).

\section{Methods}

Cats of $2 \cdot 0-4 \cdot 0 \mathrm{~kg}$ body weight and of either sex were used. Each animal was anaesthetized with sodium pentobarbitone $35 \mathrm{mg} / \mathrm{kg}$ (i.p.) and the trachea was cannulated. The eyeball was excised and the nictitating membrane with all the adjoining tissue was removed from the orbit. The tissue was placed in a Petri dish with modified Krebs solution at room temperature previously equilibrated with $95 \%$ oxygen and $5 \% \mathrm{CO}_{2}$. The composition of $\mathrm{Krebs}$ solution was as follows $(\mathrm{g} / \mathrm{l}$.): $\mathrm{NaCl}, 6.9 ; \mathrm{KCl}, 0.35 ; \mathrm{CaCl}_{2}, 0.28 ; \mathrm{MgCl}_{2}, 0.11 ; \mathrm{NaH}_{2} \mathrm{PO}_{4}, 0.12 ; \mathrm{NaHCO}_{3}, 2 \cdot 1$; glucose, 2 ; ascorbic acid $20 \mathrm{mg} / 1$. and EDTA, $1.5 \mathrm{mg} /$ litre. The medial muscle was dissected under a binocular dissecting microscope, together with the postganglionic sympathetic fibres arising from the infratrochlear nerve which innervates this smooth muscle of the nictitating membrane (Thompson, 1958). The cartilage in which the fibres of the medial muscle are inserted was fixed to the bottom of a $10 \mathrm{ml}$ organ bath. The upper end of the muscle was connected to a force displacement transducer (Grass FT 03) and the tension developed by the muscle was recorded with a Grass Polygraph. The temperature was maintained at $37^{\circ} \mathrm{C}$ and the organ bath was bubbled with a $95 \% \mathrm{O}_{2}: 5 \% \mathrm{CO}_{2}$ mixture. The infratrochlear nerve was pulled through shielded bipolar platinum electrodes for stimulation with monophasic rectangular pulses of $0.5 \mathrm{~ms}$ duration and supramaximal voltage delivered by a Grass S44 stimulator. A period of $30 \mathrm{~min}$ was allowed to elapse before starting the experiment. During this period the modified Krebs solution was replaced every 10 minutes. The resting tension of the muscle was repeatedly adjusted to $2.5 \mathrm{~g}$ and it reached a steady condition after $30-40$ minutes.

Thirty minutes after the smooth muscle was set up in the organ bath it was incubated for $30 \mathrm{~min}$ with $60 \mu \mathrm{Ci}\left(6 \mu \mathrm{Ci} / \mathrm{ml}, 116 \mathrm{ng} / \mathrm{ml}\right.$ of $( \pm)-7-\left[{ }^{3} \mathrm{H}\right]$-noradrenaline $)$ (New England Nuclear, S.A. 8.7 Ci/mM). At the end of the incubation period the tissue was washed 8 times for 1 min each time with fresh Krebs solution. Subsequently the Krebs solution was replaced every $10 \mathrm{~min}$ during the following $30 \mathrm{~min}$ and thereafter every $5 \mathrm{~min}$ for an additional $60 \mathrm{~min}$ period. The repeated washings ensured the elimination of extraneuronally bound $\left[{ }^{3} \mathrm{H}\right]$-noradrenaline.

The spontaneous outflow of radioactive products from the tissue into the bathing fluid was monitored by counting $0.5 \mathrm{ml}$ samples of the fluid which had been in contact with the tissue for 5 minutes. Eighty to 90 min after incubation with $\left[{ }^{3} \mathrm{H}\right]$-noradrenaline the spontaneous outflow of radioactive products had levelled off and the collection of samples for the assay of $\left[{ }^{3} \mathrm{H}\right]$-noradrenaline and metabolites was begun. When drugs were added to the organ bath they were replaced every time that the 
bathing fluid was renewed. The nerves were stimulated at $10 \mathrm{~Hz}$ for 5 minutes. The outflow of radioactive products was measured before, during and after the period of stimulation. Samples of $7 \mathrm{ml}$ of the bathing solution which had been in contact with the tissue were collected for chromatography. The samples were added to a beaker containing $0.4 \mathrm{ml} 1 \mathrm{~N} \mathrm{HCl}, 5 \mathrm{mg}$ EDTA and $12.5 \mathrm{mg} \mathrm{Na}_{2} \mathrm{SO}_{3}$. Samples of $0.5 \mathrm{ml}$ for estimating total radioactivity were obtained at the same time. In experiments which involved two stimulation periods the second stimulation period was carried out $50 \mathrm{~min}$ after the first.

\section{Neuronal uptake of $\left[{ }^{s} \mathrm{H}\right]$-noradrenaline}

The medial and inferior smooth muscles of the nictitating membrane were dissected free as described above. Each smooth muscle was placed in a separate beaker containing $3 \mathrm{ml}$ of the modified Krebs solution and set in a Dubnoff metabolic incubator at $37^{\circ} \mathrm{C}$ and gassed with $95 \% \mathrm{O}_{2}: 5 \% \mathrm{CO}_{2}$.

The drugs tested were added to the Krebs solution at the beginning of this preincubation period. After preincubation for $30 \mathrm{~min},( \pm)-\left[{ }^{3} \mathrm{H}\right]$-noradrenaline was added to give a final concentration of $26 \mathrm{ng} / \mathrm{ml}$ and the incubation was continued for 20 minutes. After incubation with $\left[{ }^{3} \mathrm{H}\right]$-noradrenaline the muscles were transferred to beakers containing fresh medium and incubated for a further 5 minutes. At the end of this washing period the tissues were blotted dry, weighed and homogenized with $5 \mathrm{ml}$ of cold $0.4 \mathrm{~N}$ perchloric acid containing $10 \mathrm{mg} / \mathrm{ml}$ EDTA and $12.5 \mathrm{mg} / \mathrm{ml} \mathrm{Na}_{2} \mathrm{SO}_{3}$ for analysis of endogenous noradrenaline, [ $\left.{ }^{3} \mathrm{H}\right]$-noradrenaline and its metabolites.

\section{Extraneuronal uptake of $\left[{ }^{3} \mathrm{H}\right]$-noradrenaline}

Extraneuronal uptake was measured in muscles of chronically denervated nictitating membranes. Denervation of the nictitating membrane was achieved by removing the right superior cervical ganglion under ether anaesthesia. At least 3 days after the operation, when the adrenergic nerve endings are fully degenerated (Van Orden, Bensch, Langer \& Trendelenburg, 1967), the medial and inferior muscles of the nictitating membrane were isolated as described above. The incubation of the muscles was carried out under conditions identical to those described above for neuronal uptake of noradrenaline.

The drugs tested were added during the 30 min preincubation period. $( \pm)-\left[{ }^{3} \mathrm{H}\right]-$ Noradrenaline, $100 \mathrm{ng} / \mathrm{ml}$ was added to the Krebs solution and the incubation proceeded for another 15 minutes. After incubation with $\left[{ }^{3} \mathrm{H}\right]$-noradrenaline the muscles were blotted dry, weighed and processed as described for the normal muscles. Since washings were not performed in these series of experiments the extracellular amine was calculated and subtracted from the total amine retained in the tissue assuming an extracellular space of $30 \%$ (Iversen, 1963).

As the noradrenaline taken up by extraneuronal tissues is rapidly metabolized (Lightman \& Iversen, 1969) monoamine oxidase was inhibited by injecting the animals with pargyline $(100 \mathrm{mg} / \mathrm{kg}$, i.p.) $18 \mathrm{~h}$ before the experiment and catechol$O$-methyltransferase was inhibited by adding U-0521 (3,4-dihydroxy- $\alpha$-methyl-propiophenone) $(20 \mu \mathrm{g} / \mathrm{ml})$ to the preincubation and incubation media. 


\section{Chemical methods}

Noradrenaline and its metabolites were separated by column chromatography. Portions of the tissue homogenates were brought to $\mathrm{pH} 8.2$ by the addition of two volumes of Tris- $\mathrm{HCl}$ buffer $(0.5 \mathrm{M}, \mathrm{pH} 9)$. When the samples to be analysed were portions of the Krebs solution bathing the tissue, they were brought to $\mathrm{pH} 8.2$ by titrating with Tris- $\mathrm{HCl}$ buffer $(0.5 \mathrm{M}, \mathrm{pH} \mathrm{8.4)}$. The samples were then poured into a column packed with $200 \mathrm{mg}$ of alumina (Merck). The column was washed successively with $5 \mathrm{ml}$ sodium acetate $0.2 \mathrm{M}, \mathrm{pH} 8.2$ and $1 \mathrm{ml}$ of distilled water. The effluent and washings contained the $O$-methylated metabolites of noradrenaline and were pooled for further analysis. The $\left[{ }^{3} \mathrm{H}\right]$-noradrenaline and the catechol-deaminated metabolites retained by the alumina were eluted separately with $5 \mathrm{ml}$ perchloric acid $0.04 \mathrm{~N}$ for noradrenaline followed by $6 \mathrm{ml}$ of $0.2 \mathrm{~N} \mathrm{HCl}$ for the catecholdeaminated products.

Normetanephrine was separated from the $O$-methylated-deaminated products by means of a strong cation exchange resin column. The pooled effluent and washings from the alumina column were brought to $\mathrm{pH} 6.5$ by the addition of $1 \mathrm{~N} \mathrm{HCl}$ and passed through a Dowex $50 \mathrm{~W} \times 8\left(\mathrm{Na}^{+}\right.$form ; $200-400$ mesh) column $(5 \mathrm{~mm} \times$ $25 \mathrm{~mm}$ ). The column was then washed with $5 \mathrm{ml}$ of $0 \cdot 1 \mathrm{M}$ sodium phosphate buffer, pH 6.5 and $1 \mathrm{ml}$ of distilled water. The $O$-methylated-deaminated products were not retained by the column and were assayed in a portion of the pooled effluent and washings from the Dowex column. The normetanephrine was eluted with $6 \mathrm{ml}$ of a mixture of $6 \mathrm{~N} \mathrm{HCl}$ : ethanol $96^{\circ} 1: 1(\mathrm{v} / \mathrm{v})$.

Radioactivity was measured using a mixture of toluene $666 \mathrm{ml}$, Triton X 100 , $333 \mathrm{ml}$; PPO (2,5-diphenyloxazole) $5.5 \mathrm{~g}$ and POPOP (1,4-bis-[2-(5-phenyloxazolyl)]-benzene) $0 \cdot 1 \mathrm{~g}$ as scintillator. One millilitre of the sample was dissolved in $10 \mathrm{ml}$ of the scintillator. A correction for quenching was obtained by the addition of known amounts of tritiated water.

Recoveries for noradrenaline were $95 \%$ and for normetanephrine $80 \%$. Recoveries of the other metabolites were not obtained and the results were not corrected for recoveries.

The fluorometric analysis of noradrenaline was carried out by the method of Laverty \& Taylor (1968) on a portion of the $0.04 \mathrm{~N}$ perchloric acid eluate from the alumina column. A one $\mathrm{ml}$ sample was brought to $\mathrm{pH} 6.5$ by the addition of $0.25 \mathrm{ml}$ sodium phosphate buffer $(0.4 \mathrm{M}, \mathrm{pH} 7 \cdot 4)$. Then $50 \mu \mathrm{l}$ of an iodine solution $\left(0.25 \mathrm{mg} / \mathrm{ml} \mathrm{I}_{2}\right.$ and $\left.55 \mathrm{mg} / \mathrm{ml} \mathrm{Na} \mathrm{I}\right)$, were added. Three min later $500 \mu \mathrm{l}$ of $3 \mathrm{~N}$ $\mathrm{NaOH}$ containing $12.5 \mathrm{mg} / \mathrm{ml}$ sodium sulphite and $10 \mathrm{mg} / \mathrm{ml}$ of EDTA were added. Five min after the addition of $\mathrm{NaOH}, 200 \mu \mathrm{l}$ of glacial acetic acid were added. Readings were carried out 20-40 min after the oxidation with iodine in an Aminco Bowman spectrophotofluorometer. The wave lengths for excitation and emission were 380 and $480 \mathrm{~nm}$, respectively. For the blanks, the iodine solution was added after the other reagents.

\section{Dose-response curves with noradrenaline}

The isolated medial muscle of the nictitating membrane was set up with its post-ganglionic nerve fibres as described above. One hour after the preparation was set up a cumulative frequency-response curve was determined until the maximum development of tension was obtained (usually at 25 or $50 \mathrm{~Hz}$. One 
hour after the frequency-response curve was obtained, a dose-response curve to (-)-noradrenaline was determined by adding the drug cumulatively in such a way that the concentration in the bath was increased by a factor of about 3 whenever a steady response to the previous concentration had been reached. Only one doseresponse curve to (-)-noradrenaline was determined per experiment. In control experiments the maximal development of tension obtained with nerve stimulation was of the same magnitude as the maximal response obtained with (-)-noradrenaline $(17 \cdot 2 \pm 0.6 \mathrm{~g}$ and $18 \cdot 2 \pm 0.7 \mathrm{~g}$ respectively, $n=36)$. When phenoxybenzamine was used it was added to the organ bath $30 \mathrm{~min}$ before the dose-response curve to noradrenaline was determined. Since the maximal development of tension in response to nerve stimulation was determined in every experiment, responses to exogenous noradrenaline are expressed as a percentage of the maximum tension.

Statistical calculations: Conventional procedures were used for the calculation of regressions (Snedecor \& Cochran, 1967). When the means of several groups receiving different treatments were compared with the controls a one way analysis of variance for samples of unequal sizes was applied. When the $f$ ratio revealed a difference between the means they were compared against the controls with the method of Tuckey as described by Steel \& Torrie (1960).

The following drugs were used: pargyline hydrochloride, phenoxybenzamine hydrochloride, (-)-noradrenaline bitartrate monohydrate and U-0521 (3,4-dihydroxy- $\alpha$-methylpropiophenone).

All concentrations and doses refer to the salt except for noradrenaline which is expressed as free base.

\section{Results}

\section{Effects of phenoxybenzamine on responses of the nictitating membrane to exogenous noradrenaline}

The $\alpha$-adrenoceptor blocking effects of several concentrations of phenoxybenzamine on the medial muscle of the normal nictitating membrane are shown in Fig. 1.

With increasing concentrations of phenoxybenzamine there was a progressive shift to the right and a depression of the maximum of the dose-response curve to

TABLE 1. Effects of phenoxybenzamine on responses to noradrenaline, neuronal and extraneuronal uptake of $\left[{ }^{3} \mathrm{H}\right]$-noradrenaline in the cat's nictitating membrane

\begin{tabular}{|c|c|c|c|c|c|c|c|}
\hline $\begin{array}{c}\text { Groups } \\
\text { Phenoxybenzamine } \\
(\mathrm{g} / \mathrm{ml})\end{array}$ & $n$ & $\begin{array}{c}\text { Responses } \\
\text { to (-) NA } \\
\text { Max. PBA } \\
\text { Max. cont. } \\
\text { (1) }\end{array}$ & $n$ & $\begin{array}{c}\text { Endogenous } \\
\text { content } \\
(\mu \mathrm{g} \mathrm{NA} / \mathrm{g}) \\
(2)\end{array}$ & $\begin{array}{c}\text { Neuronal } \\
\text { uptake (ng } \\
{\left[{ }^{3} \mathrm{H}\right]-\mathrm{NA} / \mu \mathrm{g} \text { NA) }} \\
(3)\end{array}$ & $n$ & $\begin{array}{c}\text { Extraneuronal } \\
\text { uptake } \\
\text { (ng }\left[{ }^{3} \mathrm{H}\right]-\mathrm{NA} / \mathrm{g} \text { ) } \\
\text { (4) }\end{array}$ \\
\hline $\begin{array}{l}\text { Controls } \\
10^{-8} \\
10^{-7} \\
0 \cdot 3 \times 10^{-6} \\
10^{-6} \\
10^{-5}\end{array}$ & $\begin{array}{r}32 \\
7 \\
7 \\
-1 \\
-6 \\
4\end{array}$ & $\begin{array}{l}0.96 \pm 0.04 \\
0.82 \pm 0.07 \\
0.71 \pm 0.04 \\
= \\
0.26 \pm 0.03 \\
0.02 \pm 0.01\end{array}$ & $\begin{array}{r}18 \\
12 \\
16 \\
4 \\
6 \\
4\end{array}$ & $\begin{array}{r}9.08 \pm 0.98 \\
8 \cdot 65 \pm 1 \cdot 80 \\
7 \cdot 38 \pm 0 \cdot 80 \\
10 \cdot 10 \pm 2 \cdot 32 \\
11.86 \pm 1 \cdot 56 \\
15 \cdot 12 \pm 1 \cdot 13^{*}\end{array}$ & $\begin{array}{c}22 \cdot 5 \pm 1 \cdot 6 \\
33 \cdot 7 \pm 3 \cdot 3 * \\
22 \cdot 2 \pm 2 \cdot 3 \\
29 \cdot 2 \pm 3 \cdot 5 \\
9 \cdot 3 \pm 1 \cdot 0^{*} \\
1 \cdot 6 \pm 0 \cdot 3 \dagger\end{array}$ & $\frac{17}{-}$ & $\begin{array}{c}137 \cdot 0 \pm 12 \cdot 0 \\
= \\
= \\
171 \cdot 0 \pm 19 \cdot 0 \\
54 \cdot 3 \pm 3 \cdot 4 \dagger\end{array}$ \\
\hline
\end{tabular}

(1) Ratio between the maximum development of tension obtained with (-) noradrenaline in the presence of phenoxybenzamine PBA and the maximum in the controls. (2) Endogenous noradrenaline was measured fluorometrically in the muscles of the nictitating membrane. (3) Neuronal uptake expressed as $\mathrm{ng}\left[{ }^{3} \mathrm{H}\right]$-noradrenaline taken up per $\mu \mathrm{g}$ of endogenous noradrenaline. (4) Extraneuronal uptake was determined in chronically denervated muscles in which monoamine oxidase and catechol-O-methyl transferase were inhibited. Results are mean values \pm s.E. of the mean. Variance analysis was applied to the groups (see Methods). $n=$ number of experiments; ${ }^{*} P<0.05$; $+P<0.01$. 
noradrenaline. With $10^{-8} \mathrm{~g} / \mathrm{ml}$ of phenoxybenzamine the shift of the dose-response curve to the right was $0.5 \mathrm{log}$ units, and there was already a decrease in the maximum response.

The $\alpha$-adrenoceptor block obtained in the presence of phenoxybenzamine was taken as the decrease in the maximum tension developed and expressed as the quotient of the maximum response to noradrenaline in the presence of phenoxybenzamine divided by the maximum response obtained in the corresponding controls (Table 1).

\section{Effects of phenoxybenzamine on neuronal accumulation of $\left[{ }^{3} \mathrm{H}\right]$-noradrenaline}

Figure 2 shows that there was a significant correlation between the accumulation of $\left[{ }^{3} \mathrm{H}\right]$-noradrenaline in the tissue, expressed as $n g\left[{ }^{3} \mathrm{H}\right]$-noradrenaline retained per $\mathrm{g}$ tissue, and the endogenous noradrenaline content expressed as $\mu \mathrm{g}$ per $\mathrm{g}$ for every individual experiment in normal nictitating membranes $(r=0.67 ; b=20.7 \pm 5.7$; $n=18 ; P<0.01)$.

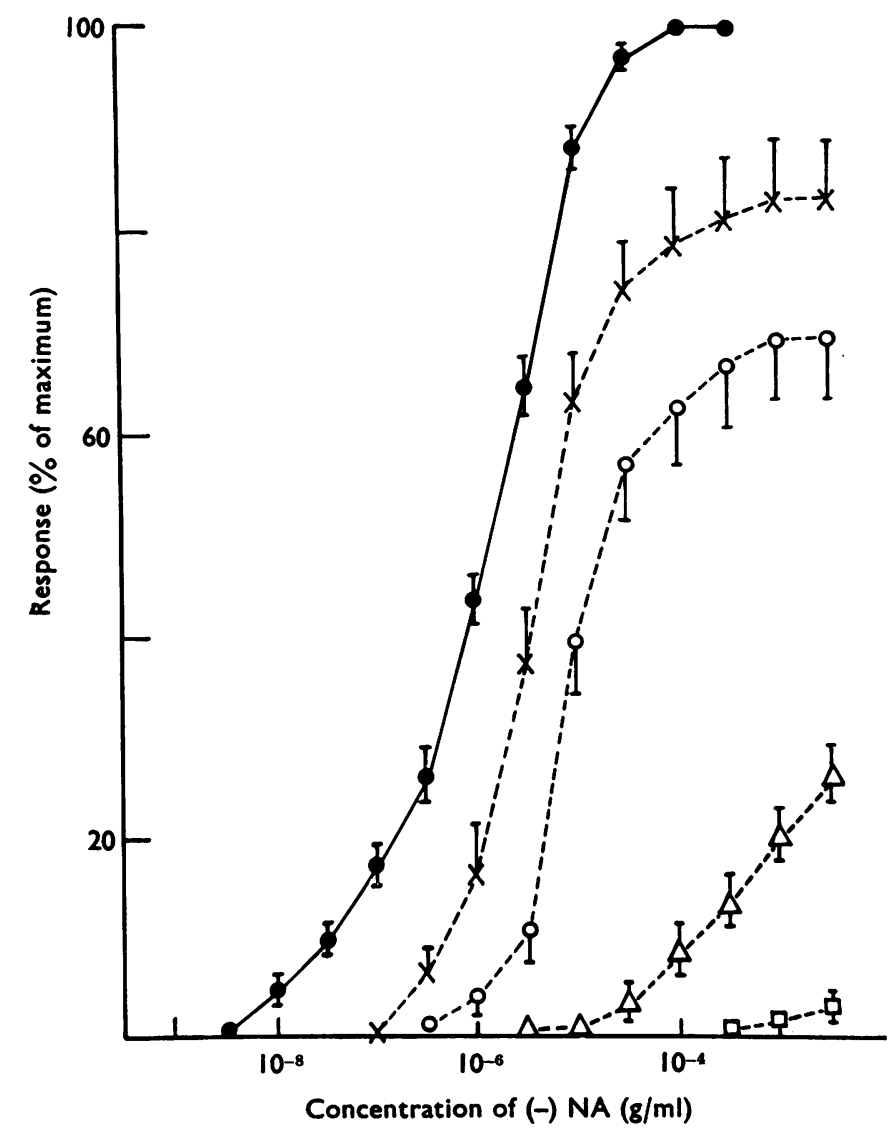

FIG. 1. Effects of phenoxybenzamine on dose-response curves to noradrenaline in the normal nictitating membrane of the cat. Ordinate: development of tension in percent of the maximum. Abscissa: concentration of $(-)$-noradrenaline (NA). phenoxybenzamine $10^{-8} \mathrm{~g} / \mathrm{ml} ; \mathrm{O}_{-}-O$, phenoxybenzamine $10^{-7} \mathrm{~g} / \mathrm{ml} ; \Delta \cdots-\triangle$, phenoxybenzamine $10^{-6} \mathrm{~g} / \mathrm{ml} ; \square \cdots-. \square$, phenoxybenzamine $10^{-5} \mathrm{~g} / \mathrm{ml}$. Values are expressed as means \pm S.E. of the mean. 


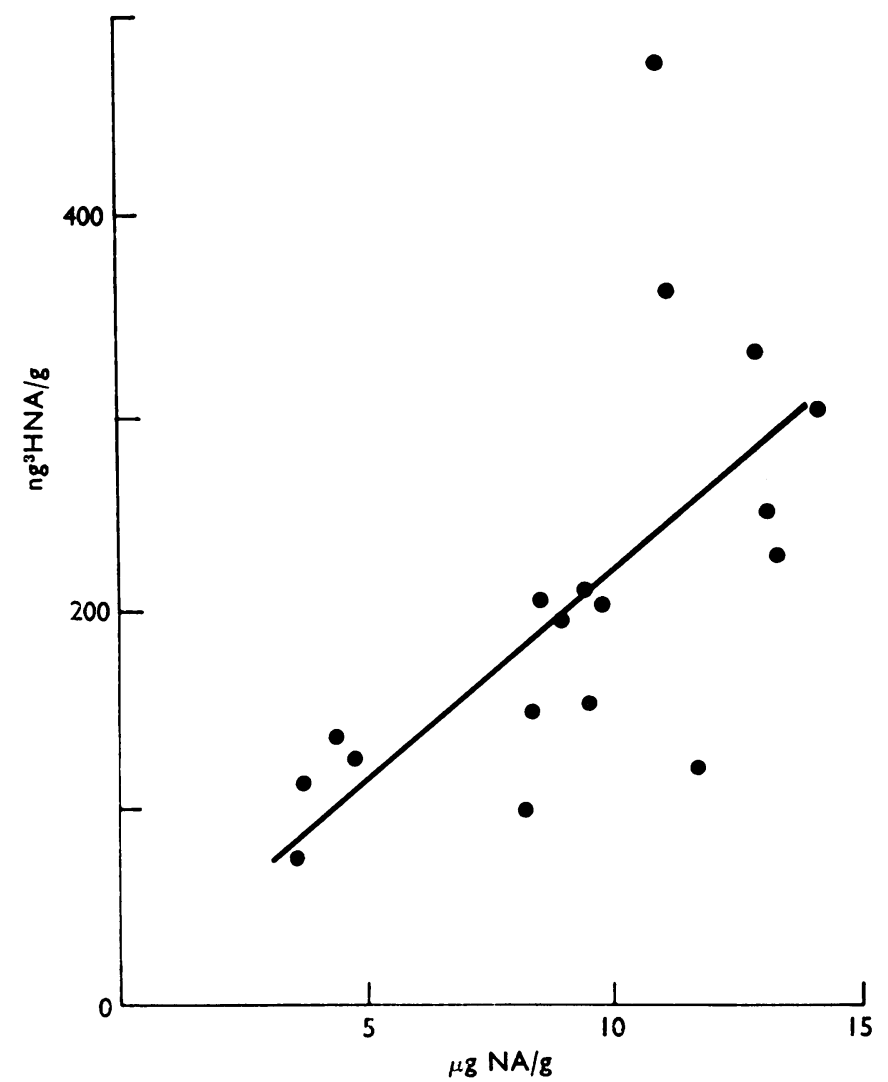

FIG. 2. Correlation between the accumulation of $\left[{ }^{3} \mathrm{H}\right]$-noradrenaline and the endogenous noradrenaline concentration in normal muscles of the nictitating membrane. Abscissa: endogenous noradrenaline concentration of the nictitating membrane ( $\mu \mathrm{g} N A / g)$ Ordinate: accumulation of $\left[{ }^{3} \mathrm{H}\right]$-noradrenaline (ng $\left.{ }^{3} \mathrm{H}-\mathrm{NA} / \mathrm{g}\right) ; r=0.67 ; n=18 ; b=20.7 \pm 5 \cdot 7 ; P<0 \cdot 01$.

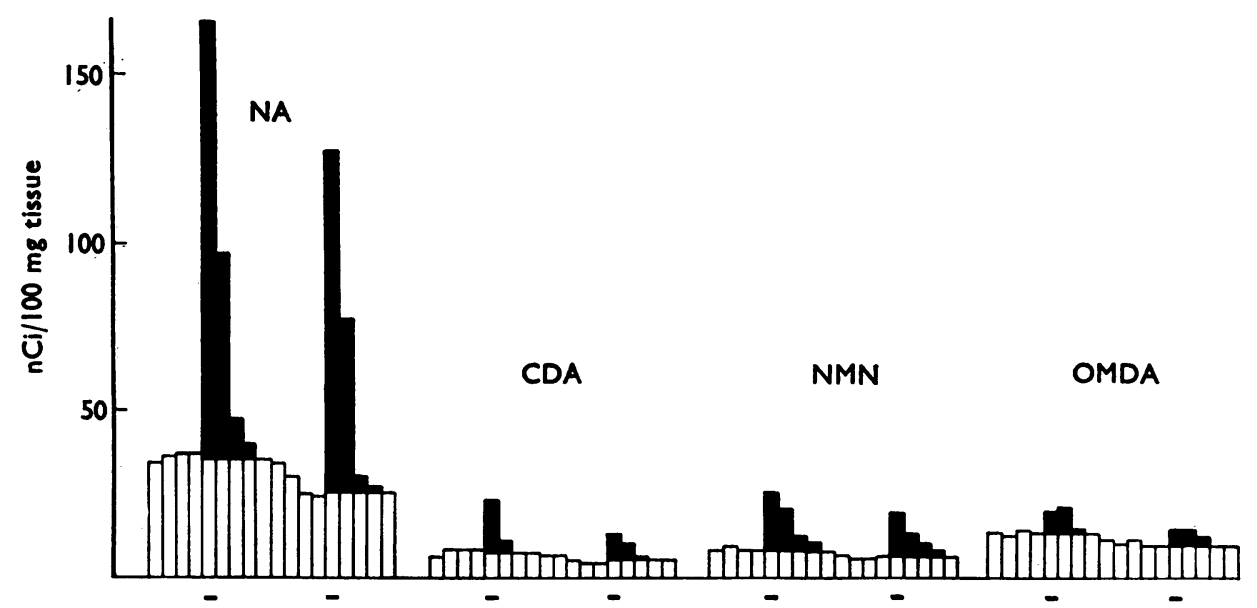

FIG. 3. Overflow of radioactive products elicited by nerve stimulation. Ordinate: nCi per $100 \mathrm{mg}$ of tissue. The bars beneath the abscissa indicate the $5 \mathrm{~min}$ period of stimulation. The open columns represent the spontaneous outflow in consecutive $5 \mathrm{~min}$ samples obtained 90 min after the end of the incubation with $\left[{ }^{3} \mathrm{H}\right]$-noradrenaline. NA, noradrenaline; CDA, catecholdeaminated metabolites ; NMN, normetanephrine ; OMDA, $O$-methylated-deaminated metabolites. The black portion is intended to represent the increased overflow produced by nerve stimulation. Nerve stimulation: $10 \mathrm{~Hz}, 0.5 \mathrm{~ms}$ duration and supramaximal voltage. The values shown are the means of four experiments. 
In view of the correlation shown in Fig. 2 the results on neuronal uptake of $\left[{ }^{3} \mathrm{H}\right]$-noradrenaline were expressed as $\mathrm{ng}$ of $\left[{ }^{3} \mathrm{H}\right]$-noradrenaline retained per $\mu \mathrm{g}$ of endogenous noradrenaline.

Table 1, shows that there were no changes in the endogenous noradrenaline content in all the groups studied except for the highest concentration of phenoxybenzamine, which showed an increase in endogenous noradrenaline. With $10^{-8} \mathrm{~g} / \mathrm{ml}$ of phenoxybenzamine there was a significant increase in the tissue accumulation of $\left[{ }^{3} \mathrm{H}\right]$-noradrenaline. With concentrations of phenoxybenzamine of $10^{-6}$ and $10^{-5}$ $\mathrm{g} / \mathrm{ml}$ there was a progressive inhibition of neuronal uptake of noradrenaline.

\section{Effects of phenoxybenzamine on extraneuronal accumulation of noradrenaline}

Table 1 shows that $10^{-6} \mathrm{~g} / \mathrm{ml}$ of phenoxybenzamine failed to inhibit extraneuronal accumulation of noradrenaline. With $10^{-5} \mathrm{~g} / \mathrm{ml}$ of phenoxybenzamine, a partial inhibition of extraneuronal accumulation of noradrenaline was observed.

\section{Effects of phenoxybenzamine on transmitter overflow elicited by nerve stimulation}

The noradrenaline stores of the medial muscles of the nictitating membrane were labelled with $\left[{ }^{3} \mathrm{H}\right]$-noradrenaline as described in Methods. When the spontaneous outflow of radioactivity had levelled off the postganglionic adrenergic fibres were stimulated at $10 \mathrm{~Hz}$ for 5 minutes. Nerve stimulation elicited an increase in overflow of $\left[{ }^{3} \mathrm{H}\right]$-noradrenaline and its metabolites (Fig. 3). The efflux of radioactivity returned to prestimulation levels $15 \mathrm{~min}$ after the end of the stimulation period. The increase in outflow of noradrenaline metabolites observed during and after nerve

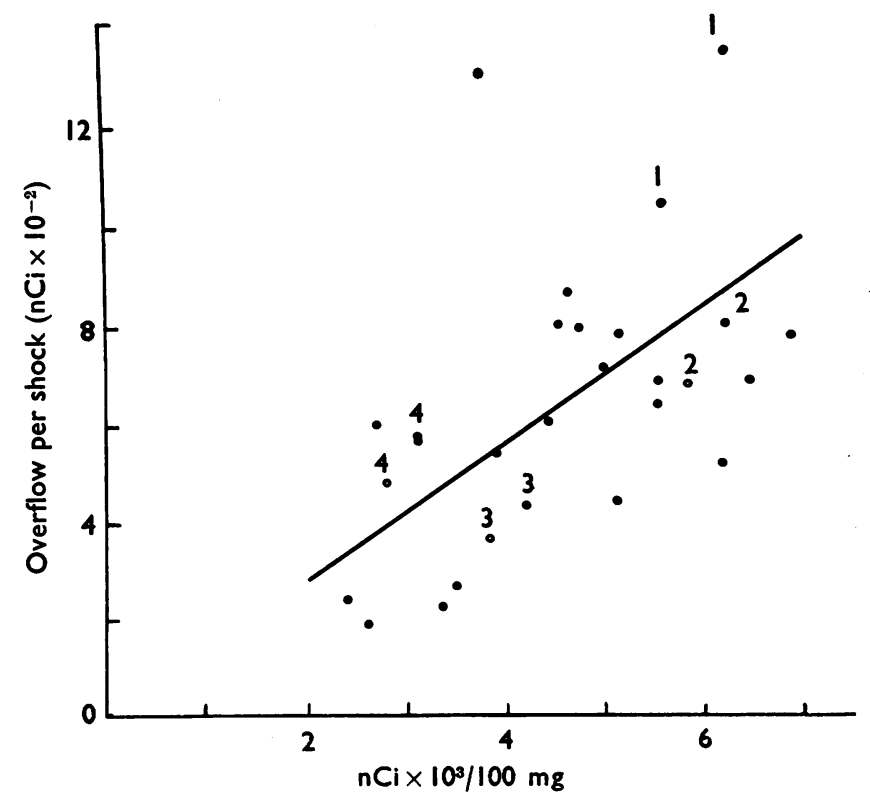

FIG. 4. Correlation between the radioactivity in the tissue and the overflow elicited by nerve stimulation. Filled circles are the results obtained in response to the first period of stimulation in individual experiments. The open circles identify the individual values in response to second stimulations in experiments in which two consecutive stimulations were performed. The numbers indicate the four experiments in which two stimulation periods were used. $r=0.556$; $b=1.44 \pm 0.44 ; n=25 ; P<0.01$. Only the filled circles were used for the calculation of the regression. 
stimulation represents released noradrenaline which has been acted upon by enzymes (Langer, 1970). Consequently, the total outflow elicited by nerve stimulation was calculated as the sum of $\left[{ }^{3} \mathrm{H}\right]$-noradrenaline plus the $\left[{ }^{3} \mathrm{H}\right]$-metabolites released in excess of the prestimulation values. Total overflow was expressed as $\mathrm{nCi}$ released per $100 \mathrm{mg}$ tissue. The radioactivity left in the tissue at the end of each experiment was also determined. Noradrenaline accounted for $86.8 \pm 2.0 \%$ of the total radioactivity left in the control tissue. A similar percentage of the total tissue radioactivity could be attributed to noradrenaline in the tissues exposed to different concentrations of phenoxybenzamine.

It was considered of interest to establish whether the total overflow of transmitter induced by nerve stimulation in control experiments correlated with the degree of tissue labelling with $\left[{ }^{3} \mathrm{H}\right]$-noradrenaline.

The total radioactivity in the smooth muscle at the beginning of the stimulation period was calculated by adding to the radioactivity left in the tissue at the end of the experiment the amount lost during the corresponding period of stimulation. A significant correlation was obtained when, for every experiment, the total radioactivity present in the tissue at the time of stimulation was plotted against the transmitter overflow $(r=0.56 ; b=1.44 \pm 0.44 ; n=25 ; P<0.01)$ (Fig. 4). The higher the radioactivity in the tissue (indicating a higher density of innervation) the larger was the overflow elicited by nerve stimulation.

In experiments in which two consecutive periods of stimulation were applied (Fig. 4) the same relation was obtained.

The variability in the overflow within the groups was reduced when it was expressed as a fraction of the radioactivity present in the tissue at the time of stimulation instead of expressing it as $\mathrm{nCi}$ released per $100 \mathrm{mg}$ of tissue. Therefore, the overflow elicited by nerve stimulation was expressed as the fraction of the total radioactivity in the tissue, that is, total $\mathrm{nCi}$ released per shock divided by total $\mathrm{nCi}$ in the tissue.

In about half of the experiments only one period of stimulation was carried out. In the remainder two stimulation periods were applied, the second 50 min after the first. There was only a small decrease (about $10 \%$ ) in the $\left[{ }^{3} \mathrm{H}\right]$ noradrenaline con-

TABLE 2. Comparison of two consecutive periods of nerve stimulation in control preparations

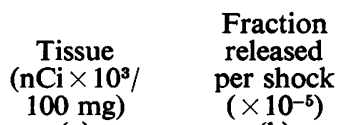

1st Stim
2nd Stim
Ratio
2nd Stim
1st Stim

(d) (a)

(b)

$$
\begin{aligned}
& 1 \cdot 60 \pm 0.30 \\
& 1 \cdot 46 \pm 0.22
\end{aligned}
$$$$
\begin{aligned}
& 5 \cdot 05 \pm 0 \cdot 85 \\
& 4 \cdot 47 \pm 0 \cdot 70
\end{aligned}
$$$$
0.89 \pm 0.04
$$

$0.93 \pm 0.04$
Metabolism ( $\%$ of the total)

(c)

$\begin{array}{cccc}\text { NA } & \text { CDA } & \text { NMN } & \text { OMDA } \\ 74 \pm 2 \cdot 7 & 6 \cdot 9 \pm 1 & 11 \pm 1 \cdot 3 & 7 \cdot 3 \pm 2 \cdot 0 \\ 75 \pm 3 \cdot 1 & 6 \cdot 2 \pm 0.9 & 12 \pm 1 \cdot 6 & 6 \cdot 3 \pm 1 \cdot 0\end{array}$

$1 \cdot 01 \pm 0.03$

$0.94 \pm 0.15$

$1 \cdot 09 \pm 0.07$

$1 \cdot 08 \pm 0 \cdot 3$

(a) Total radioactivity in the tissue. (b) Fraction of the total radioactivity released by nerve stimulation. (c) Percentage of $\left[{ }^{3} \mathrm{H}\right]$-noradrenaline and $\left[{ }^{3} \mathrm{H}\right]$-metabolites in overflow elicited by nerve stimulation. NA (noradrenaline); CDA (catechol-deaminated) : [DOPEG $(3,4$ dihydroxyphenylglycol) and DOMA (3,4 dihydroxymandelic acid)]; NMN (normetanephrine); OMDA (O-methylateddeaminated): [MOPEG (3-methoxy-4-hydroxyphenylglycol) and VMA (3-methoxy-4-hydroxymandelic acid)]. (d) Ratio between second stimulation (2nd Stim) and first stimulation (1st Stim). Results are mean values \pm s.E. of the mean for four experiments. 
tent of the stimulated muscles at the time of the second stimulation and the overflow expressed as the fraction of the tissue radioactivity released in both periods was practically the same (Table 2 ).

The pattern of noradrenaline metabolites released by stimulation did not differ when the first and second stimulation periods were compared (Table 2).

Figures 5 and 6 show the responses to nerve stimulation obtained in the experiments in which overflow of $\left[{ }^{3} \mathrm{H}\right]$-noradrenaline and its $\left[{ }^{3} \mathrm{H}\right]$-metabolites was studied. In the controls the responses were well sustained during the five minutes of stimulation. A second period of stimulation resulted in an equally sustained response of
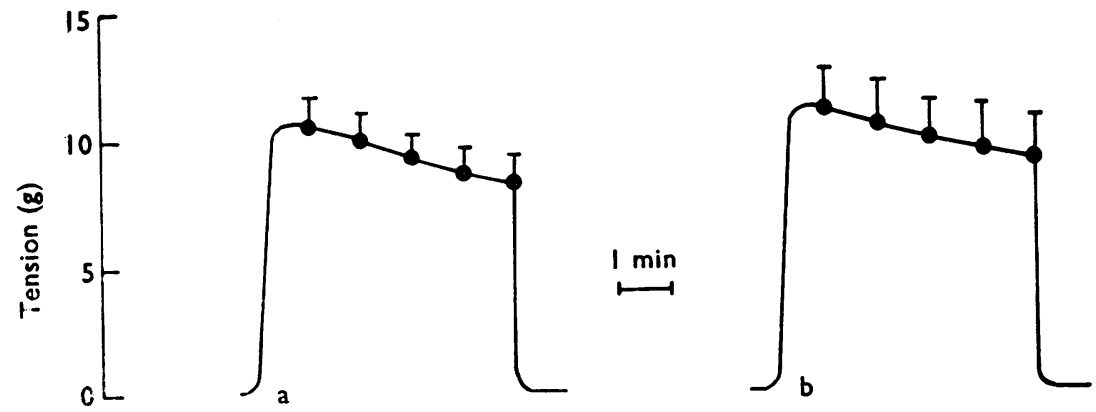

FIG. 5. Responses of the medial muscle of untreated nictitating membranes to two successive $5 \mathrm{~min}$ periods of stimulation $(10 \mathrm{~Hz}, 0.5 \mathrm{~ms}$, supramaximal voltage). The responses plotted are mean \pm S.E. of the mean. $(n=4$. $)$ a, First stimulation; $b$, second stimulation.
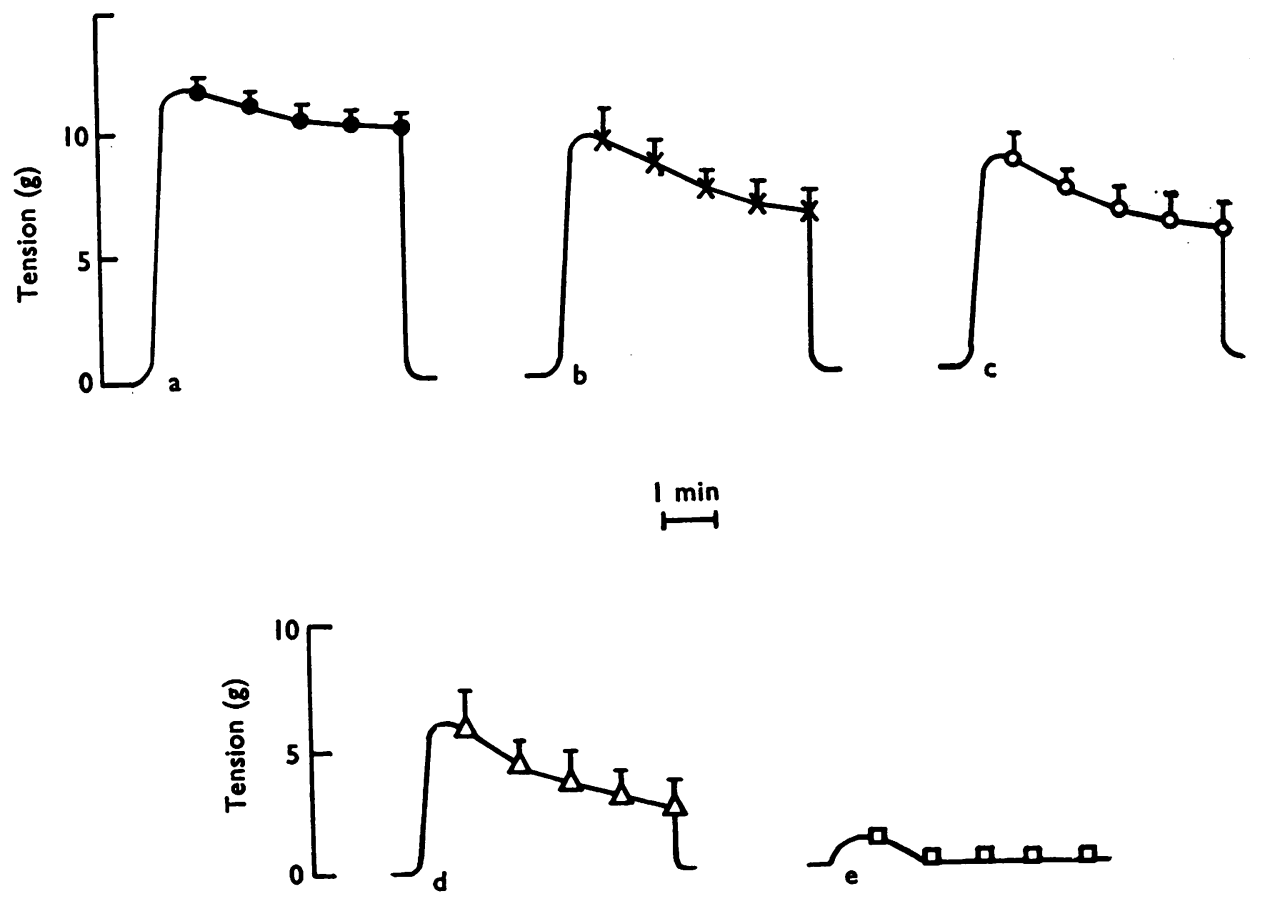

FIG. 6. Responses of the medial muscle of the nictitating membrane to a 5 min period of nerve stimulation $(10 \mathrm{~Hz}, 0.5 \mathrm{~ms}$; supramaximal voltage). The responses plotted correspond to the mean \pm S.E. of the mean. a, Controls $(n=25) ; \mathrm{b}$, phenoxybenzamine $10^{-8} \mathrm{~g} / \mathrm{ml}(n=6)$; $\mathrm{c}$, phenoxybenzamine $10^{-7} \mathrm{~g} / \mathrm{ml}(n=7) ; \mathrm{d}$, phenoxybenzamine $10^{-6} \mathrm{~g} / \mathrm{ml}(n=6)$; $\mathrm{e}$, phenoxybenzamine $10^{-5} \mathrm{~g} / \mathrm{ml}(n=6)$. 
similar magnitude (Fig. 5). In the presence of phenoxybenzamine there was a reduction in the maximal response to nerve stimulation and considerable fading of the response (Fig. 6).

Transmitter overflow induced by nerve stimulation was modified by several concentrations of phenoxybenzamine as shown in Fig. 7. A satisfactory concentrationresponse relation was obtained for the increase in transmitter overflow induced by phenoxybenzamine (Fig. 7). There were no significant differences in the degree of tissue labelling between the controls and the four concentrations of phenoxybenzamine. Consequently the expression of overflow as a fraction of the radioactivity in the tissue did not lead to distortion of the results. At $10^{-8} \mathrm{~g} / \mathrm{ml}$ of phenoxybenzamine transmitter overflow was not significantly greater than in the controls. When the concentration of phenoxybenzamine was increased to $10^{-7}$ $\mathrm{g} / \mathrm{ml}$ the increase in overflow was larger and was statistically significant (Fig. 7). No inhibition of neuronal uptake of $\left[{ }^{3} \mathrm{H}\right]$-noradrenaline was observed with $10^{-7} \mathrm{~g} / \mathrm{ml}$ of phenoxybenzamine (Table 1, Fig. 7). Thus, an experimental condition was obtained in which phenoxybenzamine increased transmitter overflow without inhibiting neuronal uptake of noradrenaline. With increasing concentrations of the drug, there was a progressive reduction in neuronal uptake coincident with a further enhancement in the overflow of the transmitter released by nerve stimulation.

No relation was found between overflow of total radioactivity and extraneuronal uptake of noradrenaline, because the latter was only inhibited at very high concentrations of phenoxybenzamine (compare Table 1, column 4, and Fig. 7). Yet $10^{-5} \mathrm{~g} / \mathrm{ml}$ of phenoxybenzamine prevented the metabolism of the noradrenaline released by stimulation. The latter confirms similar results obtained by Langer (1970).

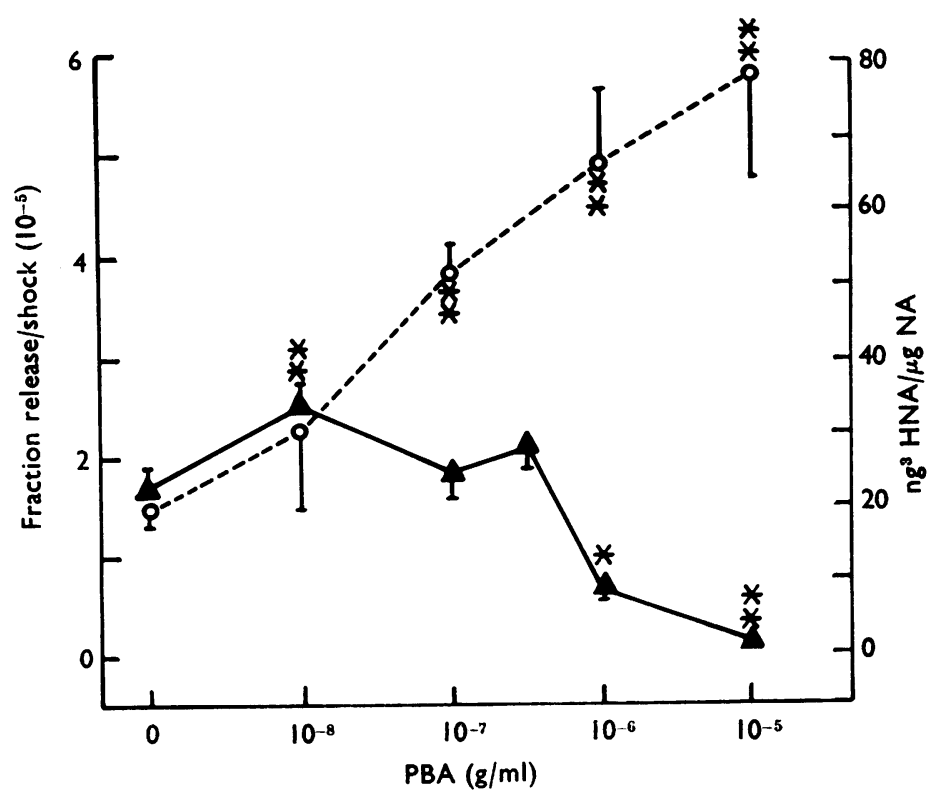

FIG. 7. Comparison of the effects of phenoxybenzamine on neuronal accumulation of $\left[{ }^{3} \mathrm{H}\right]-$ noradrenaline and on the overflow of transmitter elicited by nerve stimulation. $0-\cdots-0$, Fractional release per shock $\left(\times 10^{-5}\right) ; \Delta-\Delta$, neuronal accumulation of $\left.{ }^{3} \mathrm{H}\right]$-noradrenaline (ng $\left.{ }^{3} \mathrm{H}\right]$-noradrenaline per $\mu \mathrm{g}$ of endogenous noradrenaline). Values are mean \pm S.E. of the mean. * $P<0.05 ;{ }^{* *} P<0.01$. 
Since extraneuronal uptake could be excluded and neuronal uptake did not seem to be greatly involved in the regulation of transmitter overflow, the relation between block of $\alpha$-adrenoceptors and release of transmitter was examined more closely.

There was no correlation between the maximal response of the smooth muscles to nerve stimulation and the overflow of the transmitter in the control group ( $r=$ $0.31 ; n=25 ; P>0.05$ ). It could be argued that the failure to obtain a correlation in the controls is the result of a smaller spread of values in the abscissa and a considerable vertical variability. However, in the phenoxybenzamine treated preparations a significant correlation between the magnitude of response to nerve stimula. tion and the transmitter overflow was obtained even if the range of values for the abscissa was of the same order of magnitude than the controls (responses from 4 to $14.8 \mathrm{~g}$ ). This correlation was observed in eighteen experiments and it was significant $(r=0.51 ; b=0.31 \pm 0.13 ; P<0.05)$. Furthermore Fig. 8 shows that when the degree of the $\alpha$-adrenoceptor block was expressed as the ratio between the maximal response to stimulation in the presence and in the absence of phenoxybenzamine, and plotted against the overflow of labelled products induced by stimulation, a significant correlation was found $(r=0.63 ; b=4.19 \pm 1.06 ; n=25 ; P<0.01)$. These results are compatible with the view that there is a causal relation between the $\alpha$-adrenoceptor block and the increase in transmitter overflow obtained in the presence of phenoxybenzamine.

\section{Discussion}

The labelling of the noradrenaline stores in the nictitating membrane was carried out under experimental conditions similar to those of Langer \& Vogt (1971). These authors reported that the neurotransmitter released by nerve stimulation from the nictitating membrane had the same specific activity as the noradrenaline remaining in the tissue, indicating an homogenous labelling of the neurotransmitter stores.

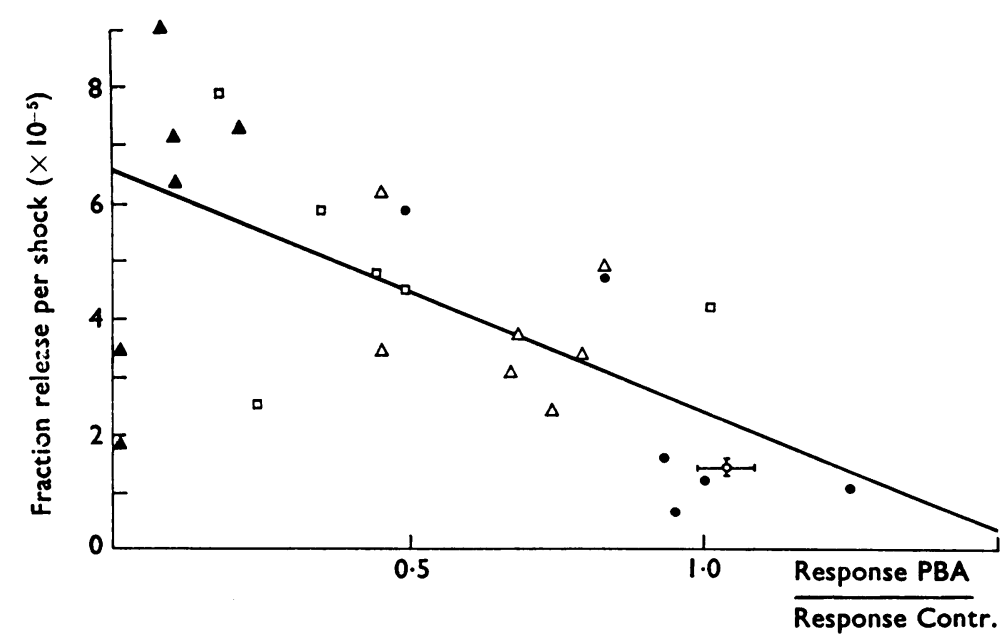

FIG. 8. Correlation between block of responses to nerve stimulation and transmitter overflow in the presence of phenoxybenzamine. Each point represents an individual experiment. Abscissa: ratio of the responses to nerve stimulation in the presence and in the absence of of phenoxybenzamine. Ordinate: fraction release per shock $\left(\times 10^{-5}\right)$ induced by a 5 min period of nerve stimulation $(10 \mathrm{~Hz}, 0.5 \mathrm{~ms}$, supramaximal voltage). The controls were not included in the correlation and are shown as mean \pm S.E. $O$, Control ;, phenoxybenzamine, $10^{-8} \mathrm{~g} / \mathrm{ml} ; \triangle$, phenoxybenzamine, $10^{-7} \mathrm{~g} / \mathrm{ml} ; \square$, phenoxybenzamine, $10^{-6} \mathrm{~g} / \mathrm{ml} ; \Delta$, phenoxybenzamine, $10^{-5} \mathrm{~g} / \mathrm{ml} . \quad r=0.63, b=4 \cdot 19 \pm 1 \cdot 06, n=25, P<0.01$. 
Therefore, it appears reasonable to assume that the results with tritiated noradrenaline are representative of the endogenous neurotransmitter.

The responses of the smooth muscle of the nictitating membrane were sustained throughout the $5 \mathrm{~min}$ of nerve stimulation, both during the first and second period of stimulation. Consequently, fatigue of the nerve or exhaustation of the noradrenaline pool immediately available for release by nerve stimulation did not appear to affect our experimental results.

The relation observed between the endogenous noradrenaline and the accumulation of $\left[{ }^{3} \mathrm{H}\right]$-noradrenaline confirms previous reports by Crout (1964) and by Trendelenburg, Draskóczy \& Pluchino (1969). The correlation between the tissue $\left[{ }^{3} \mathrm{H}\right]$-noradrenaline and the amount of transmitter released by stimulation in control experiments reflects a relation between the density of adrenergic innervation of a tissue and stimulation-induced release of noradrenaline. Several authors have expressed transmitter release as a fraction of the noradrenaline remaining in the tissue (Folkow, Häggendal \& Lisander, 1967; Langer \& Vogt, 1971; Bell \& Vogt, 1971). It appears that the expression of overflow elicited by stimulation as a fraction of the total store is an appropriate means of expressing transmitter release.

Phenoxybenzamine inhibits neuronal uptake of noradrenaline (Hertting, Axelrod \& Whitby, 1961 ; Iversen, 1967). The nature of its inhibitory action has been shown to be competitive in the rat if it is used with short preincubation periods (10 $\mathrm{min}$ ) but if the incubation period is increased the inhibition becomes non-competitive (Iversen \& Langer, 1969). The ID50 for phenoxybenzamine was approximately $1 \mu \mathrm{g} / \mathrm{ml}$, which agrees with the values reported by Iversen \& Langer (1969). In the presence of $10^{-8} \mathrm{~g} / \mathrm{ml}$ of phenoxybenzamine a significant increase in the neuronal retention of $\left[{ }^{3} \mathrm{H}\right]$-noradrenaline was obtained. This was a rather unexpected result; however, such low concentrations of phenoxybenzamine have not been studied before in their action on neuronal uptake.

The observations on extraneuronal uptake are similar to those reported by Draskóczy \& Trendelenburg (1970) and by Avakian \& Gillespie (1968) in the same species: rather large concentrations of phenoxybenzamine are required to inhibit extraneuronal accumulation of noradrenaline.

Seventy-five per cent of the total overflow of radioactivity elicited by nerve stimulation was accounted for by $\left[{ }^{3} \mathrm{H}\right]$-noradrenaline. $\left[{ }^{3} \mathrm{H}\right]$-Normetanephrine was the main metabolite and its release was increased during and after nerve stimulation. These results differ somewhat from the data of Langer (1970), who found that only $40 \%$ of the total overflow of radioactivity was accounted for by $\left[{ }^{3} \mathrm{H}\right]$-noradrenaline. Paper chromatography was used for the separation of noradrenaline and its metabolites, and the recovery for noradrenaline was $65 \%$ in the publication by Langer (1970). In the present experiments column chromatography was used, and the recovery for noradrenaline was $95 \%$. Since results in both publications were not corrected for recoveries the difference can be accounted for by the methods.

Phenoxybenzamine increased the overflow of radioactivity elicited by nerve stimulation in a concentration-dependent manner. At the lowest concentration used, $10^{-8} \mathrm{~g} / \mathrm{ml}$, the increase in overflow was not statistically significant. An increase in overflow could be prevented by the increased neuronal uptake of noradrenaline. At $10^{-7} \mathrm{~g} / \mathrm{ml}$ of phenoxybenzamine there was a significant increase in transmitter overflow to approximately 3 times that of the control values. Yet, this concentration of phenoxybenzamine had no effect on neuronal uptake of $\left[{ }^{3} \mathrm{H}\right]-$-nor- 
adrenaline. Thus, a clear dissociation between inhibition of neuronal uptake and increase in transmitter overflow was obtained with this concentration of phenoxybenzamine. With higher concentrations of the drug and coincident with the onset in the inhibition of neuronal uptake there was a further increase in the overflow of transmitter elicited by nerve stimulation. With the highest concentration of phenoxybenzamine used, $10^{-5} \mathrm{~g} / \mathrm{ml}$, the transmitter released was collected predominantly as noradrenaline, while metabolism was almost completely inhibited. The noradrenaline released by nerve stimulation which was either accumulated or metabolized in extraneuronal sites was not overlooked in our experimental conditions. The half life of noradrenaline accumulated extraneuronally is less than 10 minutes (Iversen, 1965 ; Draskóczy \& Trendelenburg, 1970) and whether it leaves the tissue as the unchanged noradrenaline or as noradrenaline metabolites, it was collected in the samples obtained after stimulation.

In view of the unexpected dissociation between inhibition of neuronal uptake and the increase in transmitter overflow elicited by stimulation the question arose as to whether observations on neuronal uptake of noradrenaline carried out in resting conditions can be extrapolated to events occurring during nerve stimulation, since changes in neuronal uptake as a consequence of stimulation have been reported (Häggendal \& Malmfors, 1969). While a definitive answer to this question cannot be provided it should be pointed out that even a 3-fold increase in the concentration of phenoxybenzamine (from $10^{-7}$ to $3 \times 10^{-7} \mathrm{~g} / \mathrm{ml}$ ) failed to inhibit neuronal uptake of noradrenaline (Fig. 7). There seems to be a real dissociation between inhibition of neuronal uptake of noradrenaline and the increase in transmitter overflow.

When the $\alpha$-adrenoceptor blocking effects of phenoxybenzamine were analysed there was a good correlation between the magnitude of the $\alpha$-adrenoceptor block induced by phenoxybenzamine and the increase in transmitter overflow elicited in the presence of the drug when individual experiments were considered (Fig. 8). With $10^{-8} \mathrm{~g} / \mathrm{ml}$ of phenoxybenzamine an increase in transmitter overflow was obtained only in the two experiments in which $\alpha$-adrenoceptor block was observed (Fig. 8).

In control experiments no relation was observed between the magnitude of responses to stimulation and the extent of transmitter overflow. This result is compatible with the view that the mechanical response of the smooth muscle does not trap the transmitter released in our experimental conditions. Similar conclusions were reached by Langer (1970). The conditions are different in perfused organs where changes in perfusion pressure can significantly influence the magnitude and the time course of transmitter overflow (Rosell, Kopin \& Axelrod, 1963).

The correlation between $\alpha$-adrenoceptor blockade and transmitter overflow appears to support the earlier view put forward by Brown \& Gillespie (1957) that the $\alpha$-adrenoceptor of the effector cell is a site of loss for the released noradrenaline. In other words, the combination of noradrenaline with the $\alpha$-adrenoceptor is partly responsible for the overflow of the transmitter being an underestimate of the output elicited by nerve stimulation. Boullin, Costa \& Brodie (1967); and Kirpekar \& Wakade (1970) recently supported this hypothesis, but it is paradoxical that phenoxybenzamine also increased the overflow of neurotransmitter in tissues in which the proportion of $\alpha$-adrenoceptors in the effector organ is small or negligible, such as isolated guinea-pig atria (Adler, Rubio \& Langer, 1970) and the perfused cat heart (Enero, Anger \& Stefano, unpublished). 
An alternative to this apparent contradiction can be provided by postulating the presence of presynaptic $\alpha$-adrenoceptors on nerve endings, irrespective of whether the receptor of the effector cell is of the $\alpha$ or $\beta$ type. These presynaptic receptors would regulate the transmitter released by nerve stimulation. A negative feedback inhibition can be envisaged in which noradrenaline released by nerve stimulation would itself inhibit further release once a threshold concentration of the transmitter is achieved in the neighbourhood of the nerve ending. Block of these receptors would lead to an increase in release of the transmitter by nerve stimulation. Consequently, the increase in transmitter overflow observed in the presence of phenoxybenzamine may not necessarily be due to the blockade of sites of loss but rather to an increase in transmitter output. The latter would make phenoxybenzamine an unsuitable tool for the study of transmitter output per shock under physiological conditions.

The concept of presynaptic receptors regulating transmitter release by nerve stimulation has been put forward for both the cholinergic and adrenergic nerve systems. Löffelholz \& Muscholl (1969) reported the presence of presynaptic muscarinic receptors regulating the output of transmitter in adrenergic nerve endings. Furthermore, Paton \& Vizi (1969) have shown that noradrenaline and adrenaline inhibit the release of acetylcholine elicited by field stimulation from the isolated gut. These effects of the catecholamines are antagonized by alpha blocking agents.

While the role of neuronal uptake of amines in regulating the concentration of noradrenaline in the synaptic cleft has gained considerable support as far as exogenous amine is concerned (Trendelenburg, 1966; Langer, Draskóczy \& Trendelenburg, 1967 ; Langer \& Trendelenburg, 1969) several discrepancies have been reported between the degree of inhibition of neuronal uptake and the increase in transmitter overflow elicited by nerve stimulation. In the presence of phenoxybenzamine and other $\alpha$-adrenoceptor blocking agents a pronounced increase in transmitter overflow induced by nerve stimulation is observed, while for either cocaine or desipramine which inhibit neuronal uptake of noradrenaline no change or a small increase in transmitter overflow is obtained (Blakeley, Brown \& Ferry, 1963 ; Geffen, 1965 ; Kirpekar \& Wakade, 1970 ; Boullin, Costa \& Brodie, 1967 ; Enero, Langer \& Stefano, unpublished). Some of these differences were analysed in a review article by Ferry (1967).

If noradrenaline can modulate its own release by nerve impulses, agents that inhibit neuronal uptake like cocaine and desipramine should exert a dual effect on transmitter overflow. An increase in the concentration of noradrenaline in the synaptic cleft resulting from inhibition of reuptake will tend to enhance transmitter overflow but the concentration of the agonist available to the presynaptic $\alpha$-adrenoceptor will be increased. The latter would trigger the postulated negative feedback mechanism leading to a decrease in transmitter output.

The authors are indebted to Dr. S. Archer of Sterling-Winthrop Research Institute for the supply of (-)-noradrenaline and to Dr. R. A. McLean of Smith, Kline \& French Laboratories for phenoxybenzamine. The technical assistance of Miss Annalis Keel and Miss Graciela Iungman is gratefully acknowledged.

\section{REFERENCES}

Adler, E., Rubio, M. C. \& LANGer, S. Z. (1970). Caminos metabólicos selectivos de la noradrenalina tritiada liberada por estímulo nervioso y por agentes farmacológicos en aurículas aisladas de cobayo. Resúmenes de Comunicaciones de la III Reunión de la Sociedad Argentina de Farmacología Experimental, p. 10-11. 
Avakian, O. M. \& Gillespie, J. S. (1968). Uptake of noradrenaline by adrenergic nerves, smooth muscle and connective tissue in isolated perfused arteries and its correlation with vasoconstrictor response. Br. J. Pharmac. Chemother., 32, 168-184.

BeLL, C. \& VOGT, M. (1971). Release of endogenous noradrenaline from an isolated muscular artery. J. Physiol., Lond., 215, 509-520.

Boullin, D. J., Costa, E. \& BRodie, B. B. (1967). Evidence that blockade of adrenergic receptors causes overflow of norepinephrine in cat's colon after nerve stimulation. J. Pharmac. exp. Ther., 157, $125-134$.

Blakeley, A. G. H., Brown, G. L. \& Ferry, C. B. (1963). Pharmacological experiments on the release of the sympathetic transmitter. J. Physiol., Lond., 167, 505-514.

Brown, G. L. \& Gillespie, J. S. (1957). The output of sympathetic transmitter from the spleen of the cat. J. Physiol., Lond., 138, 81-102.

Crout, J. R. (1964). The uptake and release of $\mathrm{H}^{3}$-norepinephrine by the guinea-pig heart in vivo. Naunyn-Schmiedebergs Arch. exp. Path. Pharmak., 248, 85-98.

Draskóczy, P. R. \& TREndelenburg, U. (1970). Intraneuronal and extraneuronal accumulation of sympathomimetic amines in the isolated nictitating membrane of the cat. $J$. Pharmac. exp. Ther., 174, 290-306.

FerRy, C. B. (1967). The autonomic nervous system. Ann. Rev. Pharmac., 7, 185-202.

Folkow, B., HägGendal, J. \& LisANDER, B. (1967). Extent of release and elimination of noradrenaline at peripheral adrenergic nerve terminals. Acta physiol. scand., 72, suppl. 307, 1-38.

GeFFEN, L. B. (1965). The effect of desmethylimipramine upon the overflow of sympathetic transmitter from the cat's spleen. J. Physiol. Lond., 181, 69-70P.

Haefely, W., Hürlimann, A. \& Thoenen, H. (1965). Relation between the rate of stimulation and the quantity of noradrenaline liberated from sympathetic nerve endings in the isolated perfused spleen of the cat. J. Physiol., Lond., 181, 48-58.

HäGGendal, J. \& MALmFors, T. (1969). The effect of nerve stimulation on the uptake of noradrenaline into the adrenergic nerve terminals. Acta physiol. scand., 75, 28-32.

Herting. G., Axelrod, J. \& Whitby, L. G. (1961). Effects of drugs on the uptake and metabolism of $\mathrm{H}^{3}$-norepinephrine. J. Pharmac. exp. Ther., 134, 146-153.

IVERSEN, L. L. (1963). The uptake of noradrenaline by the isolated perfused rat heart. Br.J. Pharmac. Chemother., 21, 523-537.

IVERSEN, L. L. (1965). The uptake of catecholamines at high perfusion concentrations in the isolated rat heart: a novel catecholamine uptake process. Br.J. Pharmac. Chemother., 25, 18-33.

IVERSEN, L. L. (1967). The Uptake and Storage of Noradrenaline in Sympathetic Nerves, p. 147. London: Cambridge University Press.

IVERSEN, L. L. \& LANGER, S. Z. (1969). Effects of phenoxybenzamine on the uptake and metabolism of noradrenaline in the cat heart and vas deferens. Br.J. Pharmac., 37, 627-637.

KIRPEKAR, S. M. \& WAKADE, A. R. (1970). Effect of $\beta$-haloalkylamines and ephedrine on noradrenaline release from the intact spleen of the cat. Br. J. Pharmac., 39, 533-541.

LANGER, S. Z. (1970). The metabolism of ${ }^{3} \mathrm{H}$-noradrenaline released by electrical stimulation from the isolated nictitating membrane of the cat and from the vas deferens of the rat. J. Physiol., Lond., 208, 515-546.

Langer, S. Z., Adler, E., Enero, M. A. \& Stefano, F. J. E. (1971). The role of the alpha receptor in regulating noradrenaline overflow by nerve stimulation. XXVth Int. Congr. Physiol. Sciences, p. 335.

Langer, S. Z., Draskóczy, P. R. \& Trendelenburg, U. (1967). Time course of the development of supersensitivity to various amines in the nictitating membrane of the pithed cat after denervation or decentralization. J. Pharmac. exp. Ther., 157, 255-273.

Langer, S. Z., Enero, M. A., Stefano, F. J. E. \& Rothlin, R. P. (1970). Acciones de la fenoxibenzamina sobre la liberación de noradrenalina por estimulación nerviosa en la membrana nictitante aislada de gato. Medicina, 30, 557-558.

LANGer, S. Z. \& TREndelenbuRG, U. (1969). The effect of a saturable uptake mechanism on the slopes of dose-response curves for sympathomimetic amines and on the shifts of dose-response curves produced by a competitive antagonist. J. Pharmac. exp. Ther., 167, 117-142.

LANGER, S. Z. \& VoGT, M. (1971). Noradrenaline release from isolated muscles of the nictitating membrane of the cat. J. Physiol., Lond., 214, 159-171.

LAVERTY, R. \& TAYLOR, K. M. (1968). The fluorimetric assay of catecholamines and related compounds: Improvements and extensions to the hydroxyindole technique. Analyt. Biochem., 22, 269-279.

LightMAN, S. L. \& IVERSEN, L. L. (1969). The role of uptake ${ }_{2}$ in the extra-neuronal metabolism of catecholamines in the isolated rat heart. Br.J. Pharmac., 37, 638-649.

Löffelholz, K. \& MuSChOll, E. (1969). A muscarinic inhibition of the noradrenaline release evoked by postganglionic sympathetic nerve stimulation. Naunyn-Schmiedebergs. Arch. exp. Path. Pharmak., 265, 1-15.

Paton, W. D. M. \& Vizi, E. S. (1969). The inhibitory action of noradrenaline and adrenaline on acetylcholine output by guinea-pig ileum longitudinal muscle strip. Br. J. Pharmac., 35, 10-28.

Rosell, S., KoPIN, I. J. \& AXELrod, J. (1963). Fate of ${ }^{3} \mathrm{H}$-noradrenaline in skeletal.muscle before and following sympathetic stimulation. Am. J. Physiol., 205, 317-321. 
SNedecor, G. W. \& Cochran, W. G. (1967). Statistical Methods, 6th ed., p. 135. Ames, Iowa: The Iowa State University Press.

Steel, R. G. D. \& Torrie, J. H. (1960). Principles and Procedures of Statistics, p. 99. New York: McGraw-Hill Book Company, Inc.

Thoenen, H., HürlimanN, A. \& HAEFElY, W. (1964). Dual site of action of phenoxybenzamine in the cat's spleen: blockade of a-adrenergic receptors and inhibition of re-uptake of neurally released norepinephrine. Experientia, 20, 272-273.

Thompson, J. W. (1958). Studies on the responses of the isolated nictitating membrane of the cat. J. Physiol., Lond., 141, 46-72.

TRENDELENBURG, U. (1966). Mechanisms of supersensitivity and subsensitivity to sympathomimetic amines. Pharmac. Rev., 18, 629-640.

Trendelendurg, U., Draskóczy, P. R. \& Pluchino, S. (1969). The density of adrenergic innervation of the cat's nictitating membrane as a factor influencing the sensitivity of the isolated preparation to 1-norepinephrine. J. Pharmac. exp. Ther., 166, 14-25.

Van Orden, L. S., Bensch, K. G., Langer, S. Z. \& Trendelenburg, U. (1967). Histochemical and fine structural aspects of the onset of denervation supersensitivity in the nictitating membrane of the spinal cat. J. Pharmac. exp. Ther., 157, 274-283.

(Received September 1, 1971) 